\title{
Ultrasonographic Evaluation of the Optic Nerve Sheath in the Diagnosis of Idiopathic Intracranial Hypertension
}

\section{Ultrassonografia da bainha do nervo óptico no diagnóstico da hipertensão intracraniana idiopática}

\author{
Marx Lima de Barros Araújo ${ }^{1}$ Benjamim Pessoa Vale \\ Lívio Pereira de Macêdo ${ }^{4}$ Anderson Batista Rodrigues ${ }^{5}$ \\ ${ }^{1}$ Neurologist, Instituto de Neurociências e Hospital Universitário da
Universidade Federal do Piauí, Teresina, PI, Brazil
${ }^{2}$ Neurosurgeon, Instituto de Neurociências, Teresina, PI, Brazil
${ }^{3}$ Neurologist, Instituto de Neurociências, Teresina, PI, Brazil
${ }^{4}$ Medical Student, Faculdade Integral Diferencial, Teresina, PI, Brazil
5 Medical Student, Universidade Federal do Piauí, Teresina, PI, Brazil
}

Irapua Ferreira Ricarte ${ }^{3}$

Tomásia Henrique Oliveira de Holanda Monteiro ${ }^{5}$

Address for correspondence Marx Lima de Barros Araújo, MD, Instituto de Neurociências e Hospital Universitário da Universidade Federal do Piauí, Rua Bartolomeu Vasconcelos, 2.440, Ilhotas, Teresina, PI, Brazil, CEP: 64015-030 (e-mail: marx.neuro@gmail.com).

Arq Bras Neurocir 2019;38:73-76.

\begin{abstract}
Intracranial hypertension $(\mathrm{ICH})$ is a life-threatening condition that can be observed in several diseases. Its clinical presentation is variable, with headache, nausea, vomiting, visual

Keywords

- intracranial hypertension

- ultrasonography

- optic nerve sheath

\section{Resumo}

Palavras-chave

- hipertensão intracraniana

- ultrassonografia

- bainha do nervo óptico disturbances, papilledema, and alterations in the level of consciousness. The gold standard for the diagnosis of ICH is still the intracranial implantation of invasive devices. Non-invasive techniques, such as ultrasonography of the optic nerve sheath (USONS), have emerged in recent years with promising clinical results. The authors report the case of a patient with progressive headache associated with visual impairment and papilledema, and the eventual diagnosis of idiopathic intracranial hypertension using USONS.

A hipertensão intracraniana (HIC) é uma condição clínica potencialmente grave, podendo ser observada na vigência de vários processos patológicos. O quadro clínico pode se manifestar com cefaleia, vômito, alterações do nível de consciência, alterações visuais e papiledema. O padrão-ouro para o diagnóstico da HIC permanece sendo através de medida invasiva, com a instalação de dispositivo intracraniano. Técnicas não invasivas, como a ultrassonografia da bainha do nervo óptico (USBNO), têm surgido nos últimos anos com resultados promissores na prática clínica. Os autores relatam o caso de um paciente jovem com história de cefaleia progressiva associada a alterações visuais e papiledema que teve o diagnóstico de hipertensão intracraniana idiopática auxiliado pela utilização da USBNO.
\end{abstract}

\section{Introduction}

Intracranial hypertension (ICH) is a frequent complication in patients with neurological disorders, and it is associated with high morbidity and mortality. As such, its early diagnosis and the institution of adequate therapeutic measures are fundamental for a good prognosis. ${ }^{1}$ These patients often require multimodal monitoring of the intracranial pressure (ICP), of the cerebral perfusion pressure (CPP), of the metabolism and received

September 21, 2015

accepted

July 4, 2016
DOI https://doi.org/

10.1055/s-0036-1594234. ISSN 0103-5355.
Copyright (c) 2019 by Thieme Revinter

Publicações Ltda, Rio de Janeiro, Brazil
License terms

() (1) $\odot \circledast$ 
tissue oxygen consumption, of the electrical brain activity, and of the body temperature, either by invasive or non-invasive devices. ${ }^{2}$ Among the aforementioned variables, ICP measurement and its maintenance at levels $<20 \mathrm{~mm} \mathrm{Hg}$ is, alone, the most important factor for a good neurological outcome. ${ }^{3}$

The gold standard for the measurement and follow-up of ICP still is the use of intracranial devices, specifically with the implantation of catheters. However, the invasive approach of this technique has multiple disadvantages and potential severe complications, such as bleeding and infections; moreover, it requires the presence of a specialized professional-in this case, a neurosurgeon-that is not available in most services. In many cases, even with the availability of a neurosurgeon, there are contraindications to the procedure, such as bleeding disorders. ${ }^{4}$

In recent years, several noninvasive methods have been developed to provide an alternative for the diagnosis of $\mathrm{ICH}$, such as transcranial neuroimaging and Doppler studies. ${ }^{8}$ However, although these methods pose less risk of complications, their accuracy remains limited.

Ultrasonography of the optic nerve sheath (USONS) is a promising diagnostic tool that can be used at the bedside. Since the optic nerve is a continuation of the central nervous system, it is encased by cerebrospinal fluid (CSF). Therefore, if the circulation of CSF is not blocked, the increased ICP is transmitted through the subarachnoid space around the optic nerve, within its sheath, especially in the retrobulbar segment. $^{12}$

The present article reports the utility of USONS in the diagnosis of a patient with idiopathic intracranial hypertension (IIH).

\section{Case Report}

A male patient, 25 years old, physician, presented to the neurology clinic with a 10 -day history of holocranial headache of mild to moderate intensity and of progressive character, reported as a "headache sensation" and associated with visual changes described as scintillating scotomas and turbidity. A general physical examination showed that the patient was obese (body mass index $[\mathrm{BMI}]=48 \mathrm{~kg} / \mathrm{m}^{2}$ ) and presented violet abdominal striae. The ophthalmologic evaluation with retinography evidenced inaccurate limits of the optic disc bilaterally, with poorly delimited margins and exudates, consistent with papilledema (-Figs. 1 and 2). There was no acuity or reduction of the visual field. The neurological examination did not show alteration of consciousness, cranial nerve palsy or focal deficit. General laboratory tests revealed only abnormalities in the cholesterol levels. There was no hormonal disturbance. A magnetic resonance imaging (MRI) exam was requested for etiological investigation and showed an empty sella and increased CSF space in the optic nerve sheath, but no other findings. Due to the clinical suspicion of $\mathrm{IIH}$, an USONS was performed, and its result suggested $\mathrm{ICH}$, with a nerve sheath of $0.52 \mathrm{~mm}$ on the right side (-Fig. 3) and of $0.54 \mathrm{~mm}$ on the left side (the normal reference value adopted in our service is up to $0.48 \mathrm{~mm}$ ). ${ }^{13}$ A lumbar puncture was performed with the patient in left lateral decubitus which

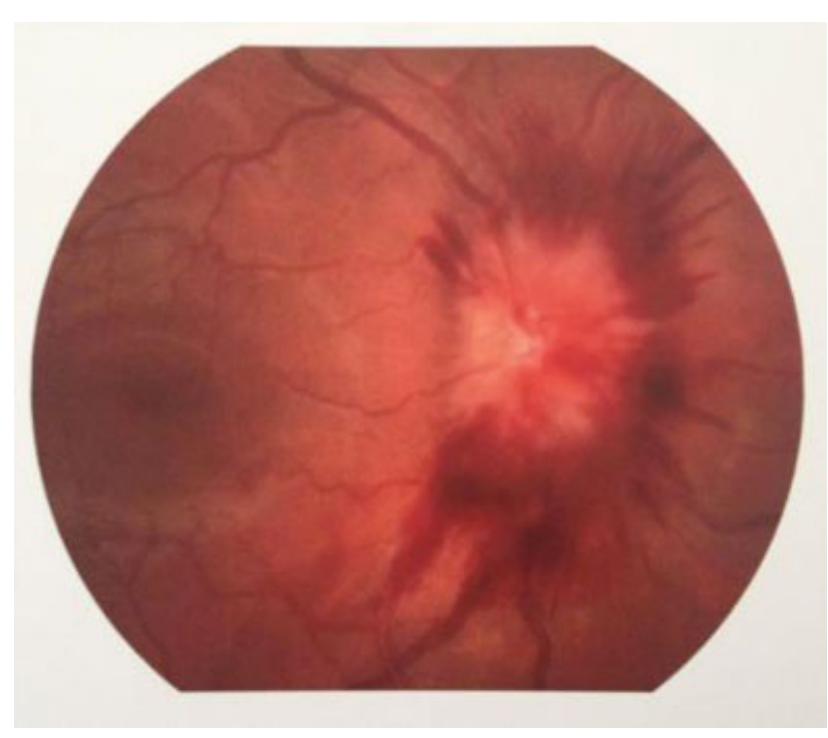

Fig. 1 Retinography-right eye-Optical disc with poorly delimited edges and exudates, consistent with papilledema.

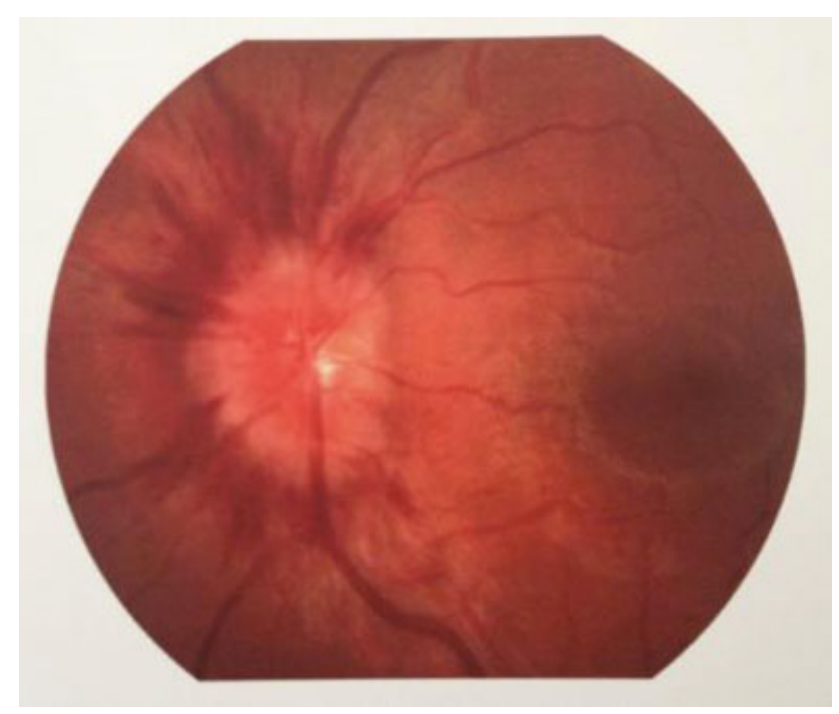

Fig. 2 Retinography-left eye-Optical disc with poorly delimited edges and exudates, consistent with papilledema.

an opening pressure of $36 \mathrm{~mm} \mathrm{Hg}$. The analysis of the CSF (cytology, cytometry, total protein, glucose, lactate dehydrogenase, and microbiological tests for bacteria and fungi detection) revealed normal findings, confirming the suggested diagnosis of IIH. Treatment with acetazolamide was started at an initial dose of $750 \mathrm{mg} / \mathrm{day}$ ( $250 \mathrm{mg}, 3$ times per day) and, as a non-pharmacological measure, the patient was oriented to lose weight through dieting and physical activities; in addition, he should be followed-up by the neurological and ophthalmic services. At a new outpatient visit, 45 days posttreatment the patient reported resolution of the headache and visual changes. An ophthalmologic evaluation with a new retinography showed resolution of the papilledema ( - Figs. 4 and 5). The patient was under nutritional monitoring, having already lost $8 \mathrm{~kg}$. 


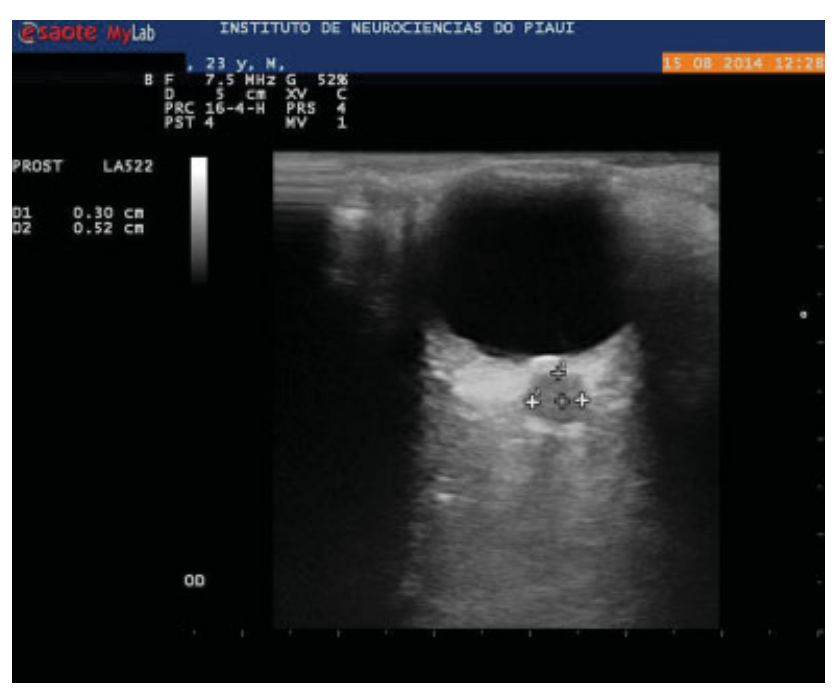

Fig. 3 Ultrasonography of the optic nerve sheath-right eye-Increased diameter of the nerve sheath (diameter $=0.52 \mathrm{~mm}$, reference value adopted at the service $=$ up to $0.48 \mathrm{~mm}$ ).

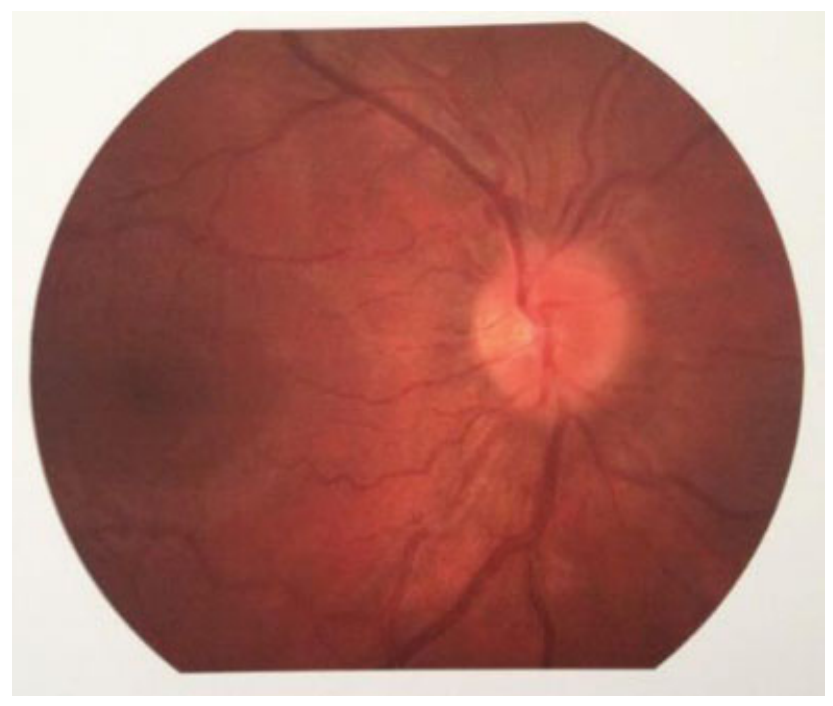

Fig. 4 Retinography after 45 days of treatment-right eye-optic disc with sharp edges and no exudates.

\section{Discussion}

Idiopathic intracranial hypertension is a pathology of unknown etiology that affects mainly young, obese women. The fundamental problem in this disease is the chronic elevation of the ICP, and its most important neurological manifestation is papilledema, which can lead to progressive optic atrophy and blindness. ${ }^{14}$

The presentation of a patient with ICH symptoms (headache, visual impairment and papilledema) should be considered a medical emergency, and a neuroimaging examination (preferably MRI) should be performed to investigate the presence of an intracranial expansive lesion. If detectable lesions are absent, the diagnosis of IIH is likely. This pathology is not associated with a specific risk of mortality, but morbidity is observed as a result of incapacitating headache and, specially, visual changes that can progress to blindness. ${ }^{15,16}$

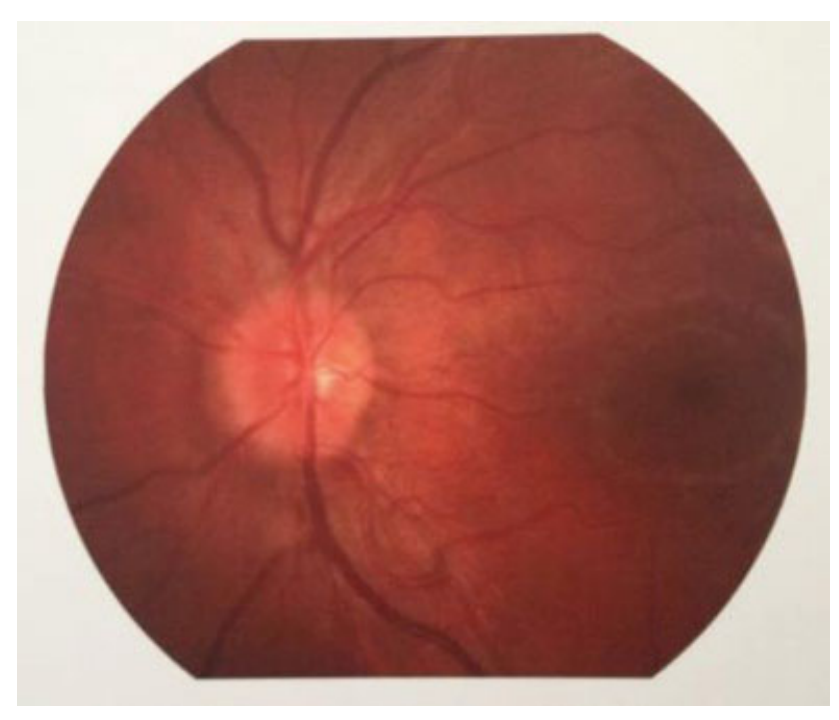

Fig. 5 Retinography after 45 days of treatment-left eye-optic disc with sharp edges and no exudates.

A study by Prunet et al showed that the normal optic nerve sheath diameter (ONSD) ranges from 0.30 to $0.49 \mathrm{~mm} .^{13}$ Soldatos et al showed that head trauma patients present a proper correlation between ONSD and ICH, demonstrating that values $>0.54 \mathrm{~mm}$ correlate with increased ICP values ( $>$ $20 \mathrm{~mm} \mathrm{Hg}$ ) with $71 \%$ sensitivity and $100 \%$ specificity. ${ }^{17}$ Roque et al also studied the usefulness of the ONSD measurement, indicating a cutoff diameter of $0.50 \mathrm{~mm} .^{18}$

\section{Conclusion}

Ultrasonography of the optic nerve sheath is a non-invasive technique, easy to perform at the bedside, with no associated complications, that can be useful in the research and monitoring of patients with clinical suspicion and diagnosis of IIH. It appears as a promising procedure for the evaluation of ICP in various contexts that can coexist with $\mathrm{ICH}$.

\section{Conflicts of Interest}

The authors have no conflicts of interest to declare.

\section{References}

1 Ropper AH. Hyperosmolar therapy for raised intracranial pressure. N Engl J Med 2012;367(08):746-752

2 Raboel PH, Bartek J Jr, Andresen M, Bellander BM, Romner B. Intracranial Pressure Monitoring: Invasive versus Non-Invasive Methods-A Review. Crit Care Res Pract 2012;2012:950393

3 Treggiari MM, Schutz N, Yanez ND, Romand JA. Role of intracranial pressure values and patterns in predicting outcome in traumatic brain injury: a systematic review. Neurocrit Care 2007;6(02):104-112

4 The Brain Trauma Foundation. The Brain Trauma Foundation. The American Association of Neurological Surgeons. The Joint Section on Neurotrauma and Critical Care. Recommendations for intracranial pressure monitoring technology. J Neurotrauma 2000;17 (6-7):497-506

5 Paramore CG, Turner DA. Relative risks of ventriculostomy infection and morbidity. Acta Neurochir (Wien) 1994;127(1-2):79-84

6 Wilberger JE Jr. Outcomes analysis: intracranial pressure monitoring. Clin Neurosurg 1997;44:439-448 
7 Rickert K, Sinson G. Intracranial pressure monitoring. Oper Tech Gen Surg 2003;5:170-175

8 Winkler F, Kastenbauer S, Yousry TA, Maerz U, Pfister HW. Discrepancies between brain CT imaging and severely raised intracranial pressure proven by ventriculostomy in adults with pneumococcal meningitis. J Neurol 2002;249(09):1292-1297

9 Hiler M, Czosnyka M, Hutchinson P, et al. Predictive value of initial computerized tomography scan, intracranial pressure, and state of autoregulation in patients with traumatic brain injury. J Neurosurg 2006;104(05):731-737

10 Hassler W, Steinmetz H, Gawlowski J. Transcranial Doppler ultrasonography in raised intracranial pressure and in intracranial circulatory arrest. J Neurosurg 1988;68(05):745-751

11 Schmidt B, Czosnyka M, Raabe A, et al. Adaptive noninvasive assessment of intracranial pressure and cerebral autoregulation. Stroke 2003;34(01):84-89

12 Hansen HC, Helmke K. The subarachnoid space surrounding the optic nerves. An ultrasound study of the optic nerve sheath. Surg Radiol Anat 1996;18(04):323-328
13 Prunet B, Asencio Y, Lacroix G, et al. Noninvasive detection of elevated intracranial pressure using a portable ultrasound system. Am J Emerg Med 2012;30(06):936-941

14 Jindal M, Hiam L, Raman A, Rejali D. Idiopathic intracranial hypertension in otolaryngology. Eur Arch Otorhinolaryngol 2009;266(06):803-806

15 Digre KB, Nakamoto BK, Warner JE, Langeberg WJ, Baggaley SK, Katz BJ. A comparison of idiopathic intracranial hypertension with and without papilledema. Headache 2009;49(02):185-193

16 Corbett JJ, Savino PJ, Thompson HS, et al. Visual loss in pseudotumor cerebri. Follow-up of 57 patients from five to 41 years and a profile of 14 patients with permanent severe visual loss. Arch Neurol 1982;39(08):461-474

17 Soldatos T, Karakitsos D, Chatzimichail K, Papathanasiou M, Gouliamos A, Karabinis A. Optic nerve sonography in the diagnostic evaluation of adult brain injury. Crit Care 2008;12(03):R67

18 Roque PJ, Wu TS, Barth L, et al. Optic nerve ultrasound for the detection of elevated intracranial pressure in the hypertensive patient. Am J Emerg Med 2012;30(08):1357-1363 